\title{
A Közép-Magyarország régió szétválasztása Budapest és környékének sikertelen erőfeszítései az együttmüködésre
}

\author{
Splitting the Central Hungary region. Unsuccessful \\ attempts of Budapest and Pest county for cooperation
}

\author{
TOSICS IVÁN
}

TOSICS Iván: ügyvezető igazgató, Városkutatás Kft.; 1093 Budapest, Lónyay u. 34.; tosics@mri.hu

Iván TOSICS: managing director, Metropolitan Research Institute; Lónyay u. 34., H-1093 Budapest, Hungary; tosics@mri.hu,

Budapest és vonzáskörzete kapcsolatának javitására a 2000-es években több erőfeszítés is történt, a Közép-Magyarország régió mellett létrejött a Budapesti Agglomeráció Fejlesztési Tanács és a Budapesti Közlekedési Szövetség. A fóváros 2004-ben azért voksolt a régió együtt maradása mellett, mert ebben az ezer szállal összetartozó térségben látta a nagyvárosi fejlödés zálogát. A kormány akkor ezt elismerte és azt is figyelembe vette, hogy a szétválasztás esetén Pest megyének járó többlettámogatásokat az ország legszegényebb részeinek juttatásaiból vonnák el. Most, egy évtizeddel később, ugyanez a helyzet, közben azonban a 2010-es években minden kooperációs intézményt felszámoltak. A régió szétválasztása helyett az együttmüködés erősitésének új formáit kellett volna feltárni, hogy a régió valódi metropolisztérségként fejlödhessen, ne csak az EU-s támogatások vélt hatásaira tekintettel.

Budapest közigazgatási területén mintegy 1,7 millió fó él, a statisztikai területi egységként számon tartott budapesti agglomeráció lakossága 2,5 millió fö, a Közép-Magyarország régió (amely a fővárosból és Pest megyéből áll) lakosságszáma 2,9 millió fö, Budapest gazdasági térségében pedig 4 millió ember lakik. Az OECD (2012) elemzése szerint Budapest nagyvárosi térsége jóval nagyobb a budapesti agglomerációnál, nagyságrendileg a Közép-Magyarország régióhoz hasonló méretű, de nem esik teljesen egybe annak területével (nem tartalmazza a Közép-Magyarország régió, pontosabban Pest megye délkeleti részét, különösen nem a Cegléden túli területeket, ugyanakkor délnyugaton csaknem Székesfehérvárig nyúlik). Az 1. ábrán Budapest (1), az agglomeráció (2) és a Közép-Magyarország régió

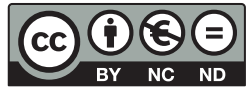


1. ábra: Budapest térsége: a város, az agglomeráció, a régió és a csapágyvárosi gyűrü Budapest and its region: the city, the agglomeration, the region and the ring of the "bearing" towns

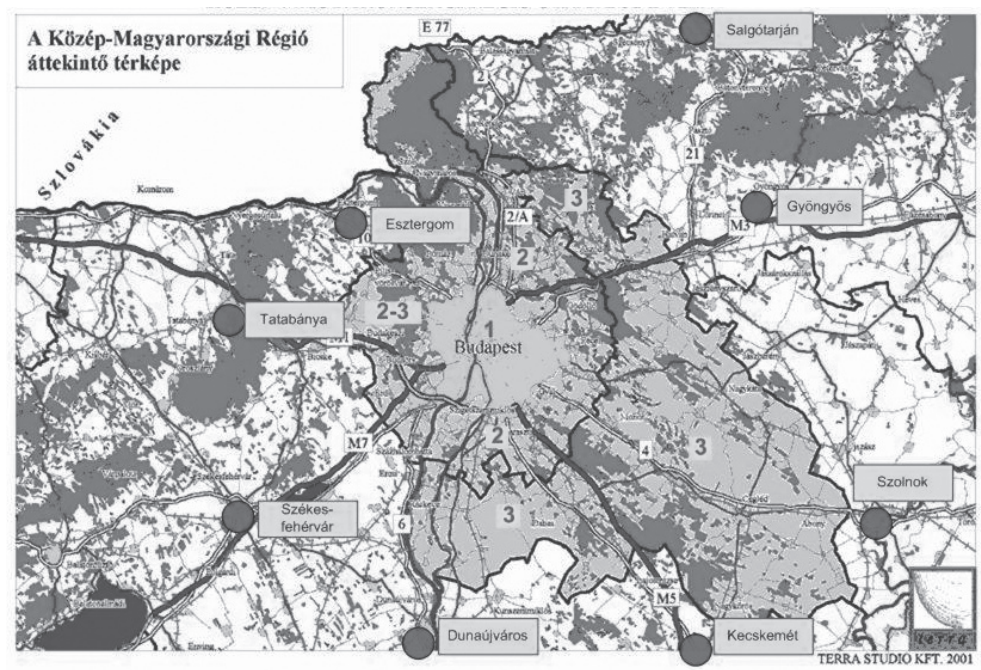

Forrás: Terra Stúdió Kft. 2001.

(3) látható, körülvéve a „csapágyvárosi gyűrűvel”, amellyel együtt ez a budapesti 4 milliós gazdasági tér.

A 2. ábrán HU001 jelöli az OECD-módszertan alapján számított budapesti nagyvárosi térséget, amelynek lakosságszáma 2,8 millió fő a 2008-as állapot szerint.

A rendszerváltozás óta jelentős szuburbanizációs folyamatok zajlanak Budapest térségében. A Budapest és az agglomeráció közötti költözések idősora (3. ábra) jól mutatja, hogy a szuburbanizáció 1994 és 2007 között volt a legjelentősebb, míg a válság óta Budapest agglomerációval szembeni vándorlási vesztesége egyre csökken és mára talán meg is szűnt. 2014-ben Budapestnek már 5 ezres vándorlási nyeresége volt az ország összes többi részével szemben.

2. ábra: Az OECD módszertana alapján számított budapesti nagyvárosi térség Budapest region according to the OECD methodology

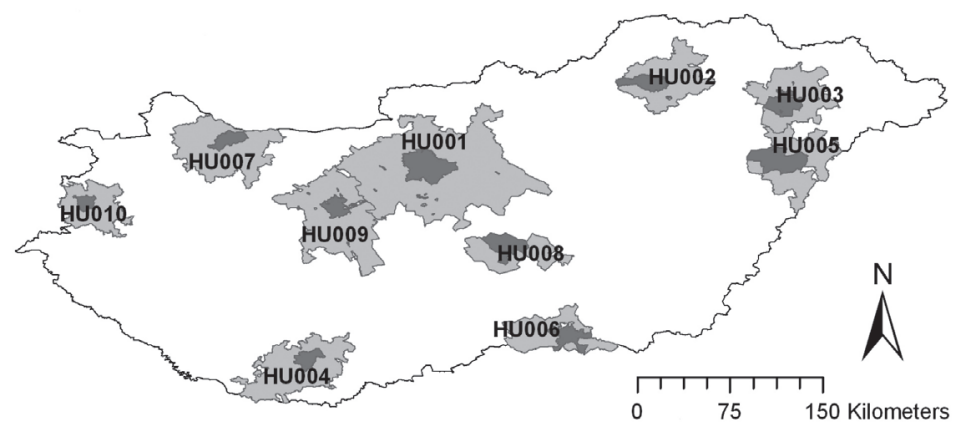

http://oecd.org/gov/regional-policy/all.pdf 
3. ábra: Budapest és az agglomeráció közötti költözések idősora (fö) Migration between Budapest and its agglomeration

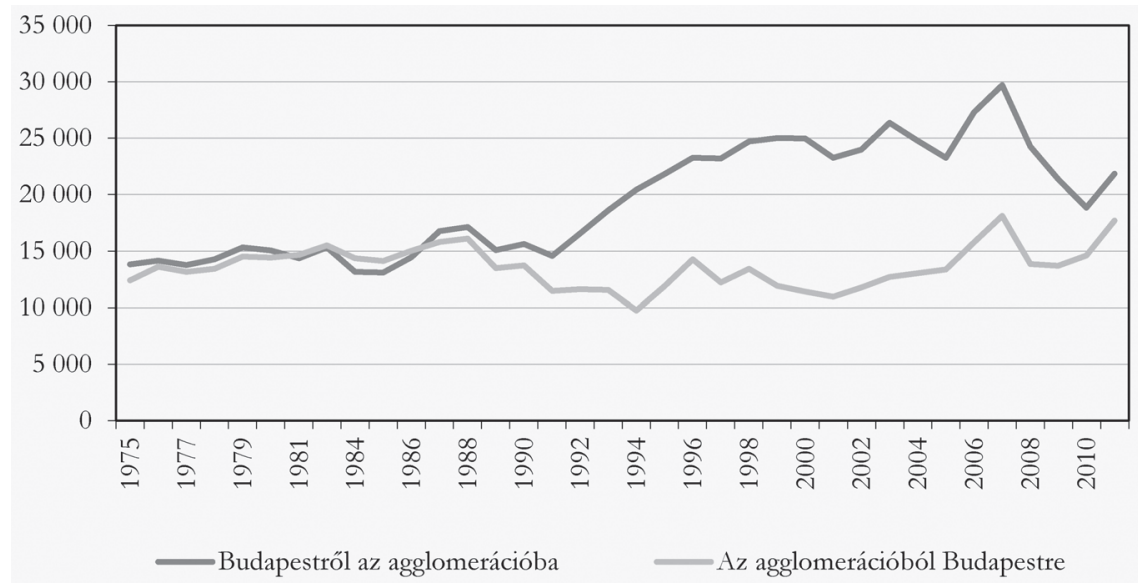

Forrás: KSH 2014.

\section{Az együttműködésre tett erőfeszítések a budapesti agglomerációban}

A nagyvárosok és vonzáskörzetük között mindenhol a világon számos érdekellentét feszül, a viszony óhatatlanul konfliktusos. Nincs ez másként Budapest és agglomerációja esetében sem. Az agglomeráció első hivatalos lehatárolására 1971-ben került sor, kizárólag statisztikai céllal 44 településre kiterjedően (a KSH 1997-ben módosította a lehatárolást Budapest és 78 település közigazgatási területére). A rendszerváltás utáni, az önkormányzatiság kiteljesítésére vonatkozó lépések sorából éppen az agglomerációs problematika kezelése maradt ki - sem az 1990-es önkormányzati törvény, sem ennek 1994-es módosítása nem tartalmazott semmilyen közigazgatási megoldást a városkörnyéki térségre. Az első igazi változást az 1996-os területfejlesztési törvény hozta, ennek alapján alapították meg a Budapesti Agglomeráció Fejlesztési Tanácsot, azzal a céllal, hogy kereteket adjon a fejlesztések koordinációjának. Jellemző azonban a konfliktusok mértékére, hogy a területfejlesztési törvény 1999-es módosításával ezt a szervezeti keretet megszüntették. Az 1990-es évek másik alapvető fontosságú elképzelése volt a Budapesti Közlekedési Szövetség létrehozása, amely azonban a bonyolult intézményi viszonyok miatt hosszú évekig elhúzódott.

A kooperációs elképzelések a 2000-es évek közepétől teljesedtek ki. Az agglomerációs együttműködés munkaszervezeteként 2005-ben újjáalakították a Budapesti Agglomerációs Fejlesztési Tanácsot (BAFT), amelynek deklarált célja a fơváros és a környéki települések fejlesztési elképzeléseinek egymással, valamint az országos és regionális koncepciókkal, programokkal történő összehangolása 
volt. A BAFT tevékenységének középpontjában az agglomerációra vonatkozó tervek kidolgoztatása állt. Így elkészült a budapesti agglomeráció területrendezési terve, a budapesti agglomeráció területfejlesztési koncepciója és stratégiai programja, valamint több ágazati fejlesztési terv is. A terveztetésen kívüli tevékenységekre azonban a BAFT sem jogköröket, sem anyagi eszközöket nem kapott.

A budapesti agglomeráció legfontosabb ágazati szervezeteként 2005-ben végre megalapították a Budapesti Közlekedési Szövetséget (BKSZ). A BKSZ hozzájárult az agglomerációs térség tömegközlekedésének szervezéséhez, harmonizálásához. E folyamat fontos lépése volt Budapest közlekedési rendszerének fejlesztési terve, amely a távlati koncepciót és a 2020-ig javasolt fejlesztéseket tartalmazta. A BKSZ-nek azonban a legföbb célját, a BKV, a VOLÁN és a MÁV egységes menetrendi, tarifa- és jegyrendszerbe szervezését nem sikerült elérnie, a három közlekedési mamutszervezet tulajdonosainak (Fővárosi Önkormányzat, minisztérium, központi kormányzat) érdekellentétei és ellenállása miatt.

\section{A területfejlesztés intézményrendszerének változásai 2010 után}

2010 után, az új politikai felállásban a területfejlesztés középszintjeként megerősítették a megyéket és jelentéktelenné tették a régiókat. A területfejlesztésről és a területrendezésről szóló törvény 2012. január 1-jei módosításával megszűntek a regionális fejlesztési tanácsok, a megyei területfejlesztési tanácsok és a kistérségi fejlesztési tanácsok. A lényeg azonban nem a területi szint változása, hanem az erőteljes centralizáció - a megyék előtérbe kerülése formálisnak tekinthető, sem megfelelő szervezeti hátteret, sem önállóságot (döntéshozási, pénzelosztási) nem kaptak.

A megyéknél kisebb kistérségi szintet is meggyengítették, a kistérségek területfejlesztési funkcióit megszüntették. A helyükbe lépő járások elsősorban a települési önkormányzatoktól elvett közigazgatási funkciókat kapták meg, területfejlesztéssel nem foglalkoznak, tehát a térségükbe tartozó települések közös gondjainak megoldásában nincs szerepük.

A centralizáció további eleme egyes fontos önkormányzati feladatok (közoktatás és egészségügy) óriási állami szervezetekbe koncentrálása, továbbá a fontos helyi közműszolgáltatások (víz-, csatorna-, hulladékszolgáltatás stb.) erősebb állami felügyelet alá vonása. A helyi települési önkormányzatok funkciói és ezzel pénzforrásai is jelentősen szükültek.

Ezek a változások a budapesti nagyvárosi térségben is végbementek, és ezzel párhuzamosan az itt létrehozott speciális kooperációs intézményeket, így a Budapesti Agglomerációs Fejlesztési Tanácsot is felszámolták. Jellemző, hogy a törvénymódosítás indokaként ,a jelenleg széttagoltan működő területfejlesztési szervezetrendszer racionalizálása" szerepelt, ami a gyakorlatban azt jelentet- 
te, hogy a BAFT jogutódja a főváros területi érintettsége esetén Budapest Főváros Önkormányzata, Pest megye területi érintettsége esetén pedig a Pest Megyei Önkormányzat lett. Ezzel megszünt a Pest megyét, Budapestet és a budapesti agglomerációt kerekasztalhoz ültető egyetlen intézmény. A BAFT funkcióját „egyeztető fórumoknak” (Budapest és Pest megye, illetve a kormány és Budapest között) kellene betölteniük. E fórumok valós működéséről információkhoz nem lehet jutni, és az is világos, hogy bármelyik pillanatban felfüggeszthetőek, megszüntethetőek.

A másik fontos kooperációs intézmény, a BKSZ ugyan a térségben működő közlekedési vállalatok tényleges integrációját nem tudta elérni, de fontos lépéseket tett ebbe az irányba, továbbá alapvető koncepcionális és tervezési feladatok tisztázásában is előrelépett. Így váratlan és az agglomerációs térség összehangolt fejlesztése elleni durva lépés volt, amikor 2011-ben a Nemzeti Fejlesztési Minisztérium és a Fővárosi Önkormányzat egy tollvonással felszámolta a BKSZ-t. Ennek helyére azóta sem lépett semmilyen intézmény, és nem véletlen, hogy napjainkban egyre jobban kiéleződnek az agglomerációs tömegközlekedés problémái.

\section{A Közép-Magyarország régió: együtt maradás 2005-ben, szétválasztás 2015-ben}

Az 1999-ben létrehozott Közép-Magyarország régió szétválasztását a 2000-es évek elejétől, de főleg az EU-hoz való csatlakozás időpontjától Pest megye vezetése folyamatosan szorgalmazta - az elmaradott területeknek járó magasabb szintű támogatás reményében. Az érvelés szerint Pest megye az ország elmaradottabb térségei közé tartozik, ugyanakkor a Budapesttel közös régió magas fejlettségi szintje miatt csak töredékét kapja azoknak a támogatásoknak, amelyekhez a fejletlen régiók hozzájutnak.

A fejletlenségre vonatkozó érvelésben ugyanakkor csak annyi az igazság, hogy a megyén belül nagyok a különbségek: a legfejlettebb agglomerációs városokhoz képest valóban vannak a megye délkeleti részén szegénynek számító települések. Az ország egészét tekintve azonban Pest megye egyáltalán nem mondható fejletlennek. Az ország településeinek területi fejlettség alapján történő besorolásánál - amely társadalmi és demográfiai, lakás- és életkörülményekre, a helyi gazdaságra vonatkozó, munkaerő-piaci, valamint infrastrukturális és környezeti mutatókból képzett komplex mutatón alapul ${ }^{1}$ - az ország 1231 fejletlennek minősített települése közül mindössze 3 esik Pest megyébe. Egy másik mutató ${ }^{2}$ fejlettségi szint szerint növekvő rangsorba rendezi az ország 197 területi egységét (járások és budapesti kerületek). Ebben a rangsorban a két legkevésbé fejlett Pest megyei járás, a nagykátai és a nagykőrösi a 71. és 74. helyet foglalja el, azaz 70 olyan járás van Magyarországon, amelyek 
fejletlenebbek a legkevésbé fejlett Pest megyei járásnál. Más szavakkal: az ország járásainak közel fele fejletlenebb, mint Pest megye legelmaradottabb járása.

2005-ben volt a Közép-Magyarország régióval kapcsolatos első döntési helyzet, amikor a régióról a 2014-2020-as programozási időszak vonatkozásában kellett dönteni. ${ }^{3}$ Pest megye egyöntetüen a régió szétválasztása mellett foglalt állást, a Fővárosi Közgyűlésben azonban a pártállásnál erősebbnek bizonyult a valós térkapcsolatokra, az agglomerációs gazdaság előnyeire való hivatkozás, és a Fővárosi Önkormányzat egyöntetűen a régió egyben tartását javasolta. A kormány ez utóbbi álláspontot fogadta el, figyelembe véve azt is, hogy Pest megye növekvő részesedése az EU-támogatásokból a többi, még inkább elmaradott megyékre jutó támogatások csökkentését jelentette volna (mivel a Magyarországnak jutó EU-s támogatás teljes nagyságát a szétválasztás nem befolyásolta).

2015 végén az egy évtizeddel korábbi érvek éppen ugyanígy fennálltak, mégis egyaránt szétválasztásra szavazott a Fővárosi Önkormányzat és Pest megye is, vagyis megszűnt a Közép-Magyarország régió. Pontosan nem tudni, csak sejteni lehet, miért engedett 2015-ben a kormány Pest megye nyomásának, és hogy Budapest miért nem állt ellen. Jól látható, hogy a régió szétválasztása nem egyszerüen egy rossz döntés, hanem a területfejlesztés országos intézményrendszere átalakításának elkerülhetetlen folytatása. Okai között ott vannak a kormányzat centralizációs törekvései, rövid távú politikai szemléletének és érdekeinek érvényesülése. Szerepet játszhat az ország területi-társadalmi-gazdasági differenciálódásának - mint alapvető problémának - figyelmen kívül hagyása. Tágabb értelemben pedig ez a lépés is beleillik a területi tervezés felszámolásának folyamatába.

\section{A Közép-Magyarország régió szétválásának várható következményei}

A szétválasztás hatásai a 2020 utáni EU-s tervezési időszakban fognak érvényesülni. Ennek szabályait ma még egyáltalán nem lehet látni. Az alábbiak azon a feltételezésen alapulnak, hogy az EU-s kohéziós politika és támogatási rendszer szabályozása nem fog alapvetően megváltozni (még ha mértéke várhatóan erősen csökkenni is fog).

Mint már említettük, Pest megye konvergenciarégióvá válása az országnak jutó támogatási összeg változatlansága miatt a legelmaradottabb, támogatásra sokkal inkább rászoruló megyékre jutó kohéziós pénzek csökkenéséhez vezet. Ez hozzá fog járulni Magyarország társadalmi, gazdasági, területi differenciálódásának erősödéséhez.

Ezt a hatást fokozhatja a beruházások területi allokációjának változása: Pest megye önálló régióként nemcsak több EU-s pénzhez, hanem a versenyjogi szabályozás szerint jobb támogatásösztönzői besoroláshoz is fog jutni. A Budapesten letelepülő beruházók már eddig sem kaphattak fejlesztési támogatást 
(sem EU-s, sem országos forrásokból), és Pest megyében is csak a települések kisebb hányadában lehet legfeljebb 35 százalékos támogatást adni a nagyvállalatoknak. Az ország legfejletlenebb régióiban ezzel szemben 50 százalékos lehet a támogatás, nyilván azzal a céllal, hogy új beruházások inkább oda települjenek. 2020-tól Pest megye önálló régióként maga is része lesz az utóbbi, 50 százalékos támogatási intenzitású kategóriának. Ezzel az ország legfejletlenebb régiói sokat veszíthetnek, hiszen ugyanolyan támogatási szint mellett Pest megye sokkal vonzóbb beruházási célpont, mint a valóban fejletlen térségek. De rosszul járhat Budapest is, mivel a környékbeli települések már nemcsak alacsonyabb adókulcsokkal, hanem 2020-tól fejlesztési támogatások ígéretével is elvándorlásra késztethetik a cégeket, az újonnan érkező beruházók pedig eleve Budapest környékén keresnek majd telephelyet maguknak. Könnyen előfordulhat, hogy a város határában egyfajta fejlesztési falat alkotva gombamódra nőnek ki a földből a zöldmezős beruházások, és a főváros barnamezős területeinek rehabilitációja gyakorlatilag lehetetlenné válik.

Pest megye gazdasági térszerkezetét szintén tovább torzíthatja az új helyzet. Ez a megye már eddig is sokat küzdött a rendkívül fejlett agglomerációs gyürü (ahol a megye lakosságának kétharmada koncentrálódik) és a jóval elmaradottabb délkeleti térség konfliktusával. Az agglomerációs gyűrű a jövőben még vonzóbb lehet a gazdaság számára, és valószínűsíthető, hogy a megyének járó támogatások végső soron nem az elmaradottabb járásokba, hanem a jobb érdekérvényesítő képességgel rendelkező agglomerációs településekbe kerülnek. Ez tovább növelné a megyén belüli differenciálódást is, és nehezen kezelhető túlnépesedést, gazdasági túlfütöttséget okozna a Budapesttel szomszédos területeken.

Az ország egyetlen igazán összetartozó térségének kettészakításával Budapest egyre jobban lemaradhat az európai nagyvárosok közötti gazdasági versenyben. Látva a város és környéke együttmúködési problémáit a mai politikusok sajnos nem azzal foglalkoztak, hogy miért nem müködtek megfelelően a nehezen létrehozott együttműködési intézmények és mechanizmusok, hanem inkább felbontották, megszüntették az összes olyan intézményi keretet, amelyeket elődeik éppen a kooperáció, a kapcsolatok gazdagodása érdekében hoztak létre. A magyar helyi politika saját érdekérvényesítést előtérbe helyező logikáját alapul véve valószínűsíthető, hogy a következő uniós pénzügyi ciklusban semmi sem fogja motiválni a két régió településeit az együttműködésre, nem lesznek közös projektek, nem készülnek egymásra figyelő fejlesztési stratégiák. Budapest és a körülötte létrehozott lyukas régió az egymás elleni harc, semmint az együttmúködés szimbólumai lesznek.

A világtrend ezzel éppen ellentétes, a szomszédos térségek közötti kapcsolatok erősítésére, az együttműködés kiterjesztésére épít. Az európai nagyobb városok arra törekednek, hogy az agglomerációjukkal együtt vagy még nagyobb térséget felölelve alkossanak együttműködő gazdasági térséget. Magyarország ebben a vonatkozásban is külön úton jár. 


\section{Jegyzetek}

1 A Kormány 105/2015. (IV. 23.) Korm. rendelete a kedvezményezett települések besorolásáról és a besorolás feltételrendszeréről.

2 A Kormány 106/2015. (IV. 23.) Korm. rendelete a kedvezményezett járások besorolásáról szóló 290/2014. (XI. 26.) Korm. rendelet módosításáról.

3 Lásd az eljárás leírását Pikler Katalin (2016) cikkében: az adott tervidőszak kezdete előtt több évvel van utoljára lehetőség változtatásokat végrehajtani a jogosultságot meghatározó regionális felosztásban.

\section{Irodalom}

KSH (2014): Migráció és lakáspiac a budapesti agglomerációban. Központi Statisztikai Hivatal, Budapest. https://www.ksh.hu/docs/hun/xftp/idoszaki/regiok/bpmigracio.pdf (Letöltés: 2016. április 26.)

OECD (2012): Redefining urban: a new way to measure metropolitan areas. OECD Publishing, Paris http://doi.org/bfn2

Pikler K. (2016): Az EU területi statisztikai rendszere (NUTS), kapcsolódva a Közép-Magyarország régió kettéválasztásának kérdéséhez. Tér és Társadalom, 2., 84-88. doi:10.17649/TET.30.2.2773

Terra Studió Kft. (2001): Közép-Magyarországi Régió Stratégiai Terv. Budapest 